\title{
The Use of Audiovisual Materials to Teach Pronunciation in the ESL/EFL Classroom
}

\section{El uso de materiales audiovisuales para enseñar la pronunciación en el aula de ESL/EFL}

DOI: $10.46932 /$ sfjdv2n5-074

Received in: Oct 1st, 2021

Accepted in: Dec 30th, 2021

\author{
Maria Gabriela Tobar Espinoza \\ Master of Linguistics Applied to Teaching English as a Foreign Language \\ Universidad de Cuenca \\ Francisca Dávila y Ricardo Muñoz \\ E-mail: gabriela.tobar@ucuenca.edu.ec \\ Yola Indaura Chica Cárdenas \\ Master of Linguistics Applied to Teaching English as a Foreign Language \\ Universidad de Cuenca \\ 12 de Abril s/n \\ E-mail: yola.chica@ucuenca.edu.ec \\ Claudia Valerie Piedra Martinez \\ Bachelor degree in English Language and Literature \\ University of Cuenca \\ Pumapungo Ave. 3-44 and Raul Andrade St. \\ E-mail:vale_piedra@hotmail.com \\ Francisco Israel Brito Saavedra \\ Bachelor degree in English Language and Literature \\ University of Cuenca \\ Cacique Chaparra and Rumiñahui 2-98 St. \\ E-mail: franciscoisraelbs@hotmail.com
}

\begin{abstract}
In the new generation of language learning and teaching, the use of technology has spread within the language classrooms. This bibliographical exploratory research was carried out to examine the use of audiovisual materials as educators' resources to teach pronunciation in the EFL/ESL classroom, their effects on students' oral production. For this purpose, 20 academic papers associated with the use of audiovisual aids in the English classroom were analyzed. Furthermore, the papers were divided into five categories such as computer-assisted method, podcasts, songs, social media, and videos. The results of the study demonstrated that audiovisual aids assisted educators and students in the teaching-learning process. They contributed to the improvement of learners' pronunciation at different English levels (beginner, intermediate, and advanced) as well as those having different ages (children, teenagers, adults) and diverse language backgrounds. Finally, this research provides information about effective strategies when using audiovisuals to help students improve their pronunciation.
\end{abstract}


Keyword: Audiovisual materials, pronunciation, English as a second language, English as a foreign language, effects.

\section{RESUMEN}

En la nueva generación de aprendizaje y enseñanza de idiomas, el uso de la tecnología se ha extendido dentro de las aulas de idiomas. Esta investigación bibliográfica exploratoria se llevó a cabo para examinar el uso de materiales audiovisuales como recursos de los educadores para enseñar la pronunciación en el aula de EFL/ESL, sus efectos en la producción oral de los estudiantes. Para ello, se analizaron 20 trabajos académicos relacionados con el uso de ayudas audiovisuales en el aula de inglés. Además, los trabajos se dividieron en cinco categorías como método asistido por ordenador, podcasts, canciones, medios sociales y vídeos. Los resultados del estudio demostraron que las ayudas audiovisuales ayudaban a los educadores y a los alumnos en el proceso de enseñanza-aprendizaje. Contribuyeron a la mejora de la pronunciación de los alumnos de diferentes niveles de inglés (principiante, intermedio y avanzado), así como de los que tenían diferentes edades (niños, adolescentes y adultos) y diversos orígenes lingüísticos. Por último, esta investigación aporta información sobre las estrategias eficaces a la hora de utilizar materiales audiovisuales para ayudar a los alumnos a mejorar su pronunciación.

Palabras clave: Materiales audiovisuales, pronunciación, inglés como segunda lengua, inglés como lengua extranjera, efectos.

\section{INTRODUCTION}

One of the most essential skills for real communication among people regardless age, gender, or nationality is pronunciation. By using the different sounds of letters and words correctly, people can convey their feelings and ideas in an effective way (Kurniati, 2016). Wulandari, Laila, and Prasetyarini, (2008) state that for a long time some EFL/ESL learners have faced pronunciation problems because of their mother tongue. Gilakjani (2011) also mentioned that "pronunciation can be one of the most difficult parts for a language learner to master and one of the least favorite topics for teachers to address in the classroom" (p.81). Moradi and Shahrokhi (2014) emphasized that one of the objectives of learning English as a second or foreign language is to achieve fluent pronunciation, and that goal cannot be achieved if students do not practice proper pronunciation in and outside the classroom. Likewise, Kurniati (2016) revealed that ESL/EFL educators find it crucial to establish the proper technique for teaching pronunciation to motivate and increase learners' interest in acquiring the language. Subsequently, in order to motivate learners to pronounce words correctly, teachers can apply successful media like videos, audios, pictures, films, etc.

There is a variety of methods and techniques that can be used in the language classroom to teach pronunciation such as the repetition technique, minimal-pair drills, audiovisual aids, etc. (Maharani, 2017). However, the use of audiovisual materials in the classroom is said to clarify ideas and concepts and that is why these types of aids can be very helpful for teachers. Moreover, the use of these materials may increase students' interest in learning pronunciation because they can understand the language better 
and they will be able to pronounce sounds correctly (Maharani, 2017). In addition, Ducate and Lomicka (2009) mentioned that it is difficult for students to identify their pronunciation mistakes and compare them with the pronunciation of native speakers of the target language. When learners have fossilization problems, the use of videos, recordings, or audios can help them to correct their mistakes by listening to the proper pronunciation of such words. Therefore, it seems necessary for ESL/EFL teachers to know how to use this material in order to be better prepared to help their students to improve their pronunciation.

It is worth mentioning that regardless of the change of the Ecuadorian English Curriculum since 2016, our country still has one of the lowest English levels proficiency. According to the Education First (EF) English Proficiency Index (EPI) (2017), Ecuador is one of the three countries with the lowest English Level in the Latin America ranking. An article published in October 2018 by Education First Company mentioned that Ecuador is placed in one of the lowest range of English language proficiency in Latin America despite the efforts of the government to pass this barrier. Therefore, focusing on developing learners' pronunciations skills can contribute to improve the English level in our country. This article may provide to Ecuadorian teachers and to others some insights about how to improve students' pronunciation in an English classroom.

This study examines the use of audiovisual materials as educators' strategies to teach pronunciation in an EFL/ESL classroom and their effects on students' oral production. It presents academic information about different types of audiovisual aids such as videos, computer-assisted programs, songs, social media, and podcast. Afterwards, a literature review of studies about the use of audiovisual aids to teach pronunciation is described. Finally, the results of these studies are analyzed and some conclusions are drawn out.

\section{TECHNOLOGY IN EDUCATION}

The word technology relates to any electronic equipment in connection with hardware, software, and networks that set up their functioning (Baek, Jung, \&amp; Kim, 2008). In the educational field, the usage of technology plays an important role since it provides better teaching and learning strategies in the classroom (Rasul, Bukhsh, \&amp; Batool, 2011). Concerning the teacher of a foreign or second language, according to Gorjian, Hayati and Pourkhoni (2013), using technology when teaching pronunciation can be beneficial in language classrooms.

\section{DEFINITION OF AUDIOVISUAL MATERIALS}

The Webster Encyclopedic Unabridged Dictionary of the English Language defines audiovisual materials as "training or educational aids directed at both, the senses of hearing and the sense of sight used in classroom instruction, library collections or the likes (Audiovisual-aids, n.d.).” 


\section{VIDEOS IN THE LANGUAGE CLASSROOM}

Videos are a set of images obtained by a camera that can be played on many devices such as computers, televisions, cellphones, etc. (Cakir, 2012). In the educational field, videos are best defined as all electronic media that have to do with digital files used by teachers to improve students' understanding of a given subject (Fee \&amp; Budde-Sung, 2014).

\section{COMPUTER-ASSISTED PROGRAMS AND SOFTWARE}

Hsu (2014) stated that computer-assisted programs and software also known as CALL (ComputerAssisted Language

Learning) are applications for language learning and teaching closely related to the use of technology using operating systems designed for computers. Additionally, its components allow teachers to create conversations for learners at different levels. This kind of aid can help students to improve on segmentals and suprasegmentals by providing them with immediate feedback.

\section{SOCIAL MEDIA TO TEACH PRONUNCIATION}

Social media is defined as online platforms of communication such as Twitter, Facebook, etc. that allow users to post interchangeable information through pictures, videos, GIFs, and so on. Moreover, the use of different interactive media tools is something new that has caught the interest of educators in the educational field as a result of their versatility.

They are designed for different kinds of learners due to the fact that in social networks learners can post audiovisual materials for academic purposes.

\section{PODCAST}

According to Takeda (2013), podcasts are digital audios or video files that can be sent using any electronic device by means of the internet. The use of podcasts through some electronic devices in the EFL or ESL classroom has widespread for teaching and learning new languages since it provides students a self-learning method giving teachers and students the opportunity to take advantage of technology (Hegelheimer \&amp; O’Bryan, 2009).

\section{SONGS IN THE LANGUAGE CLASSROOM}

Arjomad and Yazdanimoghadam (2015) define songs as literary compositions, usually in verse, to which music is put to be sung. Additionally, Harmer (2000) asserted that songs in the language classroom are a dominant stimulus for students to engage in the learning process because of the fact that 
they speak directly to their emotions, while allowing them to use their brains to assimilate better what is being learned.

\section{DEFINITION OF PRONUNCIATION}

Pronunciation is the production of a sound system in a way that does not interfere with communication either from the speakers' or the listeners' viewpoint (Paulston \&amp; Burder, 1976). Furthermore, Richards and Schmidt (2002) explained that pronunciation is a method of producing certain sounds. The four skills needed to master a language are listening, speaking, reading, and writing. Nevertheless, "Pronunciation is one of the basic requirements of learners' competence and it is also one of the most important features of language instruction" (Gilakjani, 2016). Since it is one of the most difficult skills of the language to master, pronunciation is learned by repeating sounds and correcting them when produced inaccurately. According to James (2010), the goal of English learners is to achieve a native-like accent. This, however, is not the aim of teachers since their actual goal is to enhance the pronunciation of their students. So as to do that, they would try to minimize strong accents and make them sound more natural by improving segmentals and suprasegmentals which are the two features of pronunciation.

\section{SEGMENTALS AND SUPRASEGMENTALS}

In a research led by Yan, Lin, and Liu (2018), it was mentioned that the components used when learning the pronunciation of a target language are segmentals, features concerning isolated sounds or phonemes (consonants and vowels), and suprasegmentals, features such as intonation, stress, rhythm, etc. In the same way, Parker (2000) also agreed that the pronunciation of a language is associated with some features such as stress, rhythm, intonation, linking, and reduction.

\section{PREVIOUS STUDIES}

\section{The Use of Videos on EFL/ESL Students' Pronunciation}

The use of videos within English classrooms has demonstrated a good impact in the students' pronunciation. McCrocklin (2012) analyzed the impact of the use of audio or video training on aural discrimination of vowels, the targeted goal was the discrimination of long e $/ \overline{\mathrm{e}} /$ and $\operatorname{short} \mathrm{i} / \mathbf{1} /$. This author discovered that the use of videos in language classrooms was very useful to enhance the production of segmentals. However, not only can the production of segmentals be improved, but also the production of suprasegmentals had substantial progress when using videos. In this way, a study conducted by Hismanoglu (2012) looked into whether or not internet-based video pronunciation lessons were more useful at helping students in the production of primary stress in English words as opposed to traditional 
pronunciation lessons. During the study, the students were administered a recorded pre-test and post-test. The experimental group watched two internet-based video lessons, which were retrieved from YouTube. In those videos, the students learned about word stress rules and they practiced useful vocabulary. At the same time, the control group learned about the same stress rules in a regular English class guided by their teacher. The results of this research showed that EFL learners who watched Internet-based pronunciation lessons improved on the articulation of primary stress on the last and ante-penultimate syllables of words as well as on compound adjectives and compound verbs. Nevertheless, Internet-based pronunciation lessons did not show a significant increase in the articulation of primary stress on the first and penultimate syllables of words as well as on compound nouns.

Namaziandost, Esfahani, and Hashemifarnia (2018) agreed with Hismanoglu when they studied the effect of using authentic videos on prosodic ability, which includes pause, juncture, intonation, pronunciation, and stress. The results of the study showed that the experimental group had an important improvement compared to the control group. In other words, teaching through authentic videos showed a significant impact on improving learners' prosodic ability.

Moreover, McNulty and Lazarevic (2012) supported the studies above when he examined if the use of video technology increased the proficiency in both segmentals and suprasegmentals of ESL learners. It is important to highlight that the students showed a better performance in their English oral presentations because the majority of them improved their pronunciation. In addition, the students felt motivated during the all stages of the research.

\section{The Effects of Computer Assisted Programs and Software on Pronunciation.}

Sidgi and Shaari (2017) analyzed if a group of ESL learners from a university in Baghdad found useful to learn pronunciation by using Automatic Speech Recognition (ASR). The software that they used was Eyespeak. The students attended three classes per week, one of them was taught by a teacher and the other two classes by using the software. At the end of the study, the subjects answered a questionnaire with 19 close-ended questions about the use of Eyespeak. 65\% of the students stated that Eyespeak helped them to learn pronunciation, 55\% said that they liked to use the software and 60\% said that Eyespeak is relatively easy to use. To conclude, it was established by students that ASR is a very useful tool for learning pronunciation.

Another study carried out by Wang and Munro (2004) confirmed what Sidgi and Shaari found about the advantages of using computer-based training when teaching pronunciation. They used this technology to contrast three pairs of

English vowels, long e vs short i, long u vs short $\mathrm{u}$, short e vs sheep a. This study was centered on the quality of the production of these vowels rather than the length of them. In order to carry out the study, 
the participants had to push labeled buttons to identify six minimal pairs by listening to them only twice. For the experimental group, the training was quite similar to the pre-test but the difference was that when the students made a mistake the software provided them feedback. The training process took two months with sessions of 50-60 minutes; 2-3 times per week. On the other hand, the control group had only natural speech stimuli. After two months of training, both groups, (the control and the experimental) took a posttest which was identical to the pre-test. The results showed that the experimental group improved in a $16 \%$ identifying minimal pairs of the long e vs short i vowel, $27 \%$ identifying long u vs short $\mathrm{u}$ and $12 \%$ identifying short e vs sheep a. On the other hand, the control group only improved in $2 \%$ identifying minimal pairs of the long e vs short $\mathrm{i}$ vowel, but they had a decrease of $2 \%$ in the identification of long $\mathrm{u}$ vs short $\mathrm{u}$ and short e vs sheep a sounds.

In the study of Wang and Munro (2004), the efficiency of the feedback given by software when teaching pronunciation was established. However, feedback can also be given by classmates. A clear example of this is presented in a study conducted by Luo (2016) who evaluated if peer- reviewed reading was a good method for enhancing pronunciation in ESL students. The students had to take a pre-test and a post-test. For the study, they used a software called Goldwave in which they recorded some readings. The experimental groups received feedback from their group and the teacher. On the other hand, the control group received feedback only from their teacher. In the end, the study revealed that the experimental groups outperformed the control group because they showed a better pronunciation of phonemes, words, clusters, and sentences.

\section{The Use of Social Media Network to Improve Pronunciation}

Regarding the use of social media in the EFL/ESL classroom, Xodabande (2017) perceived the use of telegram to improve learners' pronunciation at a language institute in Iran. Data were collected by administering a pre-test to 30

EFL students whose native language was Persian. The participants were asked to read sentences containing those words while their voices were recorded for the examination. Therefore, two broadcasting channels through telegram were created in order to provide different approaches to both, the experimental and the control group. During one-month, students received five pronunciation teaching messages each week containing the targeted word, its definition, an example, and a video displaying the correct pronunciation of the word. In the end, a post-test was extended to the students to verify their pronunciation progress. The results showed a positive effect when comparing the pre-test and post-test. Pronunciation in the experimental group had a significant improvement at the end of the study. The results exhibited that the use of social network telegram is a useful tool when teaching pronunciation in an EFL classroom. 
In regards to the results of Xodabande's research, a study carried out by Mompean and FouzGonzález (2016) mentioned that the use of social media networks in language instruction provides a positive effect on the pronunciation of EFL learners from a language school in Murcia (Spain) by using Twitter. During the pre-test, the students were asked to link the words to colors according to an image while their oral production was considered. After the pre-test, 7 to 10 mispronounced words were selected to create several tweets containing videos and audios displaying a native-like pronunciation. Furthermore, the tweets were sent to the students twice a day to make sure they have read them. Finally, an oral examination post-test using the same words of the pre-test was administered to analyze the progress on pronunciation. The results of the research showed that the use of Twitter in the language classroom provided beneficial effects in the learning of pronunciation; students were able to pronounce properly most of the targeted words given at the beginning.

\section{The Use of Podcasts}

Fouz-González (2019) investigated how the use of podcasts in the language classroom can improve students' pronunciation. The investigation took place in a phonetic module of a degree in English studies in Spain. The purpose of the study was to analyze the contrast of the English $(\mathrm{s}-\mathrm{z})$ and the pronunciation of the English (b-d-g) as stops since these features are sometimes fossilized. First, students completed some activities by listening to podcast having words with the target features. After that, they were asked to record themselves using the same words for peer evaluation. The results of the study revealed that the use of podcasts in language instruction had a positive effect on the pronunciation of

EFL learners. Even though the control and the experimental group displayed different results, both demonstrated the effectiveness of podcast on pronunciation.

In another research, Farangi, Nejadghanbar, Askary, and Ghorbani (2015) conducted a study to discover the effective use of podcasting to improve pronunciation at a high school in Iran. All participants' speaking skills were tested before the study. Then, students were interviewed by English teachers for 10 sessions of 30 minutes where they focused on improving their speaking skills. Afterward, the interviews were recorded to be sent to the teachers in order to make comments and feedback on a written paper to be handed to the learners. At the end of the study, the students were interviewed by the same teachers and tested again on their speaking skills. The results showed that the students improved their speaking subskills such as pronunciation, intonation, and stress in a significant way.

\section{The Use of Songs to Improve Pronunciation}

Regarding oral production, Moradi and Shahrokhi (2014) led research to know how pronunciation was affected when using songs in the EFL classroom at an English school in Isfahan, Iran. During the 
procedure, the students were given the lyrics of a song in which they were supposed to read and look for new words. Then, the participants listened to the song while they performed different activities including singing, repetition, and memorization. At the end, the same method of the pre-test was applied in a posttest for the analysis. The result of the study established that different features of pronunciation such as intonation, pause, and stress were successfully learned. Moreover, the articulation of diphthongs, triphthongs, vowels, and consonants was satisfyingly improved by the students.

In another study, Duarte, Tinjacá, and Carrero, (2012) supported the results found by Moradi and Shahrokhi (2014) regarding pronunciation. The research was carried out in a public school in Bogota, Colombia. In this stage, 10 songs were selected, considering vocabulary and grammar, to provide students with some activities such as singing, filling the blanks, and practicing pronunciation. The results of the study showed that students improved their oral communication skills such as pronunciation and modulation in a significant way.

\section{METHOD}

In order to obtain adequate sources for this exploratory bibliographic research synthesis, a thorough search was performed. Different research papers focusing on the use of audiovisual materials affecting pronunciation in

EFL/ESL learners were analyzed. The articles examined were empirical studies that have used any audiovisual material to teach pronunciation in an EFL or ESL classroom. Furthermore, 20 peer-reviewed articles were selected from a list of academic research studies related to the use of audiovisual materials to teach pronunciation within classrooms; they were retrieved from Google Scholar, ERIC, Toronto University Repository and Researchgate. In addition, to develop the theoretical framework we gathered information from different books, papers, and articles that study the influence of audiovisual materials on students' pronunciation. After the selection, the articles for the analysis were classified according to different criteria such as year of publication, age, English level, the native language of the learners, segmentals and suprasegmentals, and type of audiovisual aids.

\section{ANALYSIS}

A great deal of the audiovisual (AV) aids focusses on oral production in the EFL/ESL classroom but mainly on pronunciation. Maharani (2017) claimed that audiovisual aids engage students and teachers in the learning process providing them with methods and techniques to teach effectively and giving students support in their progress as learners.

It is important to point out that students' age and interests should be taken into account. For example, Duarte, Tinjacá, and Carrero (2012) explained that it is better and faster to learn EFL/ESL 
pronunciation at an early age as children can better imitate correct stress patterns than teenagers and adults. Moradi and Shahrokhi (2014) informed songs are an entertaining way to learn how to pronounce correctly different features of the English language.

A high number of studies regarding computer-assisted methods and videos were carried out with adults as they felt comfortable learning English pronunciation by using them. For example, Hismanoglu (2012) provided internet-based video lessons, Kirgoz (2011) recorded students' voices through interviews to analyze their progress and to provide appropriate feedback. On the other hand, McNulty and Lazarevic (2012) used authentic videos to teach students not only a correct pronunciation but also a correct register, gestures, paralinguistic cues, etc.

The use of AV materials plays an important role on oral production not only because they enhance learner's overall pronunciation, but also, they strongly affect segmentals and suprasegmentals. As Garrigues (1999, as cited in Yangklang, 2013) declared pronunciation is the basis of competent spoken communication and it has diverse components such as sounds, stress, and variation in pitch, which can be enhanced by the use of AV aids. For instance, Yangklang (2013) found that stress was the most important feature of pronunciation to be improved. In the same way, Yin (2009, as cited in Yangklang, 2013) stated it is directly connected to the enhancement of the general speaking ability. As it is shown in the research of McNulty and Lazarevic (2012), by placing the stress in the correct position words can be better understood by listeners.

Therefore, some studies focus on suprasegmental features of the language such as fluency, intonation, stress, pause, and juncture. Luo (2016) ascertained that suprasegmentals are crucial in oral production because they provide the speaker with a better performance which allows the listener to understand clearly the message. In addition, the author concluded in his research that mastering suprasegmentals are more important for better performance in learning pronunciation.

Regarding segmentals, it is worth to mention that the native language of each participants influenced the learning process. Namaziandost, Esfahani, and Hashemifarnia (2018) explained it is difficult for learners with Asian language backgrounds to produce the sounds of $/ \mathrm{p} / \mathrm{and} / \mathrm{r} / \mathrm{which}$ are used in the English language. In the same way, Spanish speakers cannot distinguish the sounds of $/ \mathrm{sh} / \mathrm{and} / \mathrm{ch} /$ produced in the target language.

\section{CONCLUSIONS}

It is difficult for some EFL/ESL teachers to establish an effective method not only to teach pronunciation but also to build up the students' interest and keep them motivated to pronounce words correctly (Kurniati, 2016). The research studies analyzed in this paper presented suitable and sufficient 
information to conclude that AV materials are beneficial to improve EFL/ESL pronunciation in the learning process.

For instance, Hsu (2014), Namaziandost, Esfahani, and Hashemifarnia (2018), Wulandari, Laila, and Prasetyarini (2008), and Maharani (2017) stated that the use of audiovisual materials in language classrooms improved students' pronunciation in both features - segmentals and suprasegmentals - in a significant way facilitating their oral production.

Despite "students may have problems learning the pronunciation of EFL/ESL at the beginning of the class when using audiovisual aids" (Maharani, 2017), Wulandari, Laila, and Prasetyarini, (2008) stated that audiovisual aids are an adequate technique not only to improve students' pronunciation, but also to give them a chance to be encouraged in the course of the language learning process. Additionally, the authors also mention in the study that audiovisual aids were best described for students and teachers as successful tools to facilitate the acquisition of any language skills and to spark the interest of the user to learn. Teachers in the educational context should use methods and techniques through audiovisual aids to enhance the teaching and learning process regarding pronunciation. 


\section{REFERENCES}

[1] Arjomad, M., \& Yazdanimoghadam, M. (2015). The effect of listening to music on the pronunciation of lower intermediate Iranian EFL learners. International Journal of Education and Research, 3(3), 101-112.

[2] Audiovisual-Aids.(n.d.). The Webster Encyclopedia Unabridged Dictionary of the English Language. Retrieved from https://www.merriam-webster.com/dictionary/audiovisuals

[3] Baek, Y., Jung, J., \& Kim, B. (2008). What makes teachers use technology in the classroom? Exploring the factors affecting facilitation of technology with a Korean sample. Computers \& Education, 50(1), 224-234.

[4] Cakir, I. (2012). Promoting Correct Pronunciation through Supported Audio Materials for EFL Learners. Online Submission, 4(3), 1801-1812.

[5] Duarte, M., Tinjacá, L. M., \& Carrero, M. (2012). Using songs to encourage sixth graders to develop English speaking skills. Profile Issues in TeachersProfessional Development, 14(1), 11-28.

[6] Ducate, L., \& Lomicka, L. (2009). Podcasting: An effective tool for honing language students' pronunciation?. Language Learning \& Technology, 13(3), 66.

[7] Education First. (2017). EF English Proficiency Index. Retrieved from https://www.ef.com.ec/epi/regions/latin-america/

[8] Farangi, M. R., Nejadghanbar, H., Askary, F., \& Ghorbani, A. (2015). The effects of podcasting on EFL upper-intermediate learners' speaking skills. CALL-EJ Online, 16(2), 16.

[9] Fee, A., \& Budde-Sung, A. E. (2014). Using video effectively in diverse classes: what students want. Journal of Management Education, 38(6), 843-874.

[10] Fouz-González, J. (2019). Podcast-based pronunciation training: Enhancing FL learners' perception and production of fossilised segmental features. ReCALL, 31(2), 150-169.

[11] Garrigues, S. (1999). Overcoming pronunciation problems of English teachers in Asia. Retrieved from http://asianbridges.com/pac2/presentations/garrigues.html.

[12] Gilakjani, A. P. (2011). A study on the situation of pronunciation instruction in ESL/EFL classrooms. Journal of Studies in Education, 1(1), 1-15.

[13] Gilakjani, A. P. (2016). English pronunciation instruction: A literature review. International Journal of Research in English Education, 1(1), 1-6.

[14] Gorjian, B., Hayati, A., \& Pourkhoni, P. (2013). Using PRAAT software in teaching prosodic features to EFL learners. Procedia-Social and Behavioral Sciences, 84, 34-40.

[15] Harmer, J. (2000). How to Teach Pronunciation. (2nd ed.). Pearson Education Limited.

England: Longman. 
[16] Hegelheimer, V. \& O’Bryan, A. (2009). Mobile Technologies, Podcasting and Language Education. IGI Global, 19. Doi: 10.4018/978-1-60566-190-2.ch018

[17] Hismanoglu, M. (2012). Teaching Word Stress to Turkish EFL (English as a Foreign Language) Learners through Internet-Based Video Lessons. Eric. Retrieved from https://files.eric.ed.gov/fulltext/ED530678.pdf

[18] Hsu, W. (2014). The effects of Audiovisual support on EFL learners' productive vocabulary. ReCALL, 26(1), 62-79.

[19] James, R. B. (2010). Teaching pronunciation gets a bad RAP: A framework for teaching pronunciation. Hankuk: University of foreign studies.

[20] Kurniati, E. (2016). Teaching Pronunciation by Using Games and Audio Visual Media. Proceedings of ISELT FBS Universitas Negeri Padang, 4(1), 237-245.

[21] Luo, B. (2016). Evaluating a computer-assisted pronunciation training (CAPT) technique for efficient classroom instruction. Computer Assisted Language Learning, 29(3), 451-476.

[22] Maharani, S. (2017). The Effectiveness of Audio-Visual Aids in Teaching Pronunciation. School of Teacher Training and Education, Sebelas Maret University, 15(5), 96-102.

[23] McCrocklin, S. (2012). Effect of Audio vs. Video on Aural Discrimination of Vowels. TESL-EJ, $16(2), \mathrm{n} 2$.

[24] McNulty, A., \& Lazarevic, B. (2012). Best practices in using video technology to promote second language acquisition. Teaching English with technology, 12(3), 49-61.

[25] Mompean, J. A., \& Fouz-González, J. (2016). Twitter-based EFL pronunciation instruction. Language Learning \& Technology, 20(1), 166-190.

[26] Moradi, F., \& Shahrokhi, M. (2014). The Effect of Listening to Music on Iranian Children's Segmental and Suprasegmental Pronunciation. English Language Teaching, 7(6), 128-142.

[27] Namaziandost, E., Esfahani, F. R., \&amp; Hashemifarnia, A. (2018). The Impact of Using Authentic Videos on Prosodic Ability among Foreign Language Learners. International Journal of Instruction, 11(4), 375-390.

[28] Parker, M. (2000, January). Pronunciation \& grammar: Using video and audio activities. In English Teaching Forum (Vol. 38, No. 1, pp. 24-31).

[29] Paulston, C. B., \& Bruder, M. N. (1976). Teaching English as a Second Language: Techniques and Procedures. Department of General Linguistics of University of Pittsburgh.

[30] Rasul, S., Bukhsh, Q., \& Batool, S. (2011). A study to analyze the effectiveness of audiovisual process at university level. Procedia-Social and Behavioral Sciences, 28, 78-81.

[31] Richards, J. C., \& Schmidt, R. W. (2002). Longman dictionary of language teaching and applied linguistics. Routledge. 
[32] Shohel, M. M. C., \& Power, T. (2010). Introducing mobile technology for enhancing teaching and learning in Bangladesh: teacher perspectives. Open Learning: The Journal of Open, Distance and eLearning, 25(3), 201-215

[33] Sidgi, L. F. S., \& Shaari, A. J. (2017). The Usefulness of Automatic Speech Recognition (ASR) Eyespeak Software in Improving Iraqi EFL Students' Pronunciation. Advances in Language and Literary Studies, 8(1), 221-226.

[34] Takeda, M. (2013). The Effect of Podcast Tasks on Students' Engagement And Performance in a Beginning Level Japanese Language Course. Eric. Retrieved from https://eric.ed.gov/?id=ED553322

[35] Wang, X., \& Munro, M. J. (2004). Computer-based training for learning English vowel Contrasts. System, 32(4), 539-552.

[36] Wang, Y. B., \& Lee, L. S. (2015). Supervised detection and unsupervised discovery of pronunciation error patterns for computer-assisted language learning. IEEE/ACM Transactions on Audio, Speech, and Language Processing, 23(3), 564-579.

[37] Wulandari, M. (2019). Improving Efl Learners'speaking Proficiency Through Instagram Vlog. LLT Journal: A Journal on Language and Language Teaching, 22(1), 111-125.

[38] Xodabande, I. (2017). The effectiveness of social media network telegram in teaching English language pronunciation to Iranian EFL learners. Cogent education, 4(1), 1347081.

[39] Yan, H., Lin, J., \& Liu, Y. (2018). EFL Pronunciation Training with Computer-Assisted Adaptive Peer Review. English Language Teaching, 11(11), 74-82.

[40] Yangklang, W. (2013). Improving English Stress and Intonation Pronunciation of the First Year Students of Nakhon Ratchasima Rajabhat University through an e-Learning. ScienceDirect, 91, $444-$ 452. https://doi.org/10.1016/j.sbspro.2013.08.442

[41] Yin, S. C., Rose, R., Saz, O., \& Lleida, E. (2009, April). A study of pronunciation verification in a speech therapy application. In 2009 IEEE International Conference on Acoustics, Speech and Signal Processing (pp. 4609-4612). IEEE. 